\title{
Skyscraper Indicator and its Application in the UK
}

\author{
Arvydas Jadevicius
}

'The skyscraper is the great architectural contribution of modern capitalistic society and is even one of the yardsticks for twentieth-century superheroes, but no one had ever really connected it with the quintessential feature of modern capitalistic history - the business cycle'

Thornton (2005, p.51)

\section{A B S T R A C T}

Objective: The research examines Skyscraper Indicator and its application in the UK. Until more recently, it was thought that this indicator was not suitable in gaging trajectory of Britain's economy. The current study is therefore set to investigate whether Skyscraper Indicator can be used as a potential leading indicator for the UK.

Research Design \& Methods: Research employs dummy variable regression to test the hypothesis. The study selects quarterly UK GDP and GDP per capita series over Q1 1960 - Q4 2014 period as macro variables and a series of dummies for construction starts, durations and completions of the record-breaking buildings in the UK.

Findings: Despite some of the methodological limitations, estimates suggest that the announcement of the construction of tallest building in the UK is related to national GDP.

Implications \& Recommendations: To make robust economic forecasts, analysts may therefore use the announcement of the construction of the record breaking skyscraper as a possible bell-weather in gaging future direction of the UK economy. They may turn their gaze towards the London skyline when contemplating UK market movements.

Contribution \& Value Added: The paper adds additional evidence on the contested Skyscraper Indicator issue.

\begin{tabular}{ll}
\hline Article type: & research paper \\
Keywords: & Crisis; Economy; Indicator; Skyscraper; UK \\
JEL codes: & C1, C2, E3,
\end{tabular}

Received: 29 September $2015 \quad$ Revised: 18 March $2016 \quad$ Accepted: 15 May 2016

\section{Suggested citation:}

Jadevcius, A. (2016). Skyscraper Indicator and its Application in the UK. Entrepreneurial Business and Economics Review, 4(2), 37-49, DOI: http://dx.doi.org/10.15678/EBER.2016.040204 


\section{INTRODUCTION}

Since the 17th century, when it became easier to produce the alloy (Roberts, 1983), steel structures became a backbone of the building industry and high-rise building in particular (Briody, 2009). At the end of 18th century further advancements in building engineering almost entirely eliminated building height constraints. As such, the height of the building was no longer determined based on commercial feasibility analysis only (Skelton, Bouchlaghem, Demian,\& Anumba, 2010; Barr, Mizrach,\& Mundra, 2015). By building upwards, developers were able to increase floor-space on any given plot of land to generate greater profits (The Economist, 2015), as well as address major economic and geographic challenges cities were facing throughout generations (Knight Frank, 2015).

Interestingly, almost a century ago Clark and Kingston (1930) estimated that the 'true economic height' of the skyscraper is no more than 63 storeys with anything above generating 'diminishing returns'. Considering a need for extra steel and concrete, more elevators, stairs and sprinklers and an increase in operational costs, the optimal height of the skyscraper has not probably changed after hundred years (Watts, Kalita,\& Maclean, 2007; The Economist, 2015).

This so called 'profit maximising builder' model however has been contested (Barr et al., 2011) as the high rise buildings are considered by some as being more than just a shelter (Barr et al., 2015), and that developers are still building record-breaking towers disregarding their bottom line (Clark and Kingston, 1930; Barr, 2010a; Barr, 2010b).

Commentators, including Thornton (2005), Barr et al. (2011; 2015), Lawrence (2012) and the Economist (2015a), therefore noticed an interesting correlation between construction of the tallest building in the world and economic crisis. As the Economist (2015a) reports, there are nearly 100 buildings over 200 meters under construction worldwide - a record breaking numbers. Kingdom Tower in Saudi Arabia is under construction which will be the tallest building in the World (Jivanda, 2014). Once completed, the Okhta Centre, Gazprom Neft's headquarters, will be the tallest building in Europe (Kononova, 2009). Shanghai Tower will be the second-tallest building in the world and tallest building in China (Flannery, 2015). Seeing these developments in the world economy, one may question financial soundness of these structures.

A conventional theory suggests that during times of easy credit when interest rates are low, businesses expand and hire more people to produce their goods and services. This then triggers demand for space, which is followed by an increase in construction activity. A need for space, competition for land and 'cheap capital', makes long-term capital intensive projects (skyscrapers) more attractive relative to short-term and less-capital intensive ones (shorter buildings). Thornton (2005) coined this expansionary economic condition as 'Cantillon effect'.

The skyscraper project is then announced and construction begun during the late phase of the boom in the business cycle (Thornton, 2005; Watts at al., 2007; Hanke, 2010). However, after several years, business cycle turns (Jadevicius \& Huston, 2014) with the skyscraper being completed during the early phase of the economic correction (Thornton, 2005). Again, knowing the propensity for business activities to follow a downward and upward movement around its long-term growth trend, and a time needed to complete a superstructure, one may wonder a rationale for building a record breaking skyscraper. 
Though determinants of skyscraper height have not been well understood (Barr et al., 2015), few explanations as to why developers are aiming for such heights exist. For Watts et al. (2007) it is population growth and urbanisation. Helsley and Strange (2008) suggest a symbolic nature of super-tall buildings - a desire to have 'the tallest' building in the city is part of the 'dissipative competition over the prize of being tallest', i.e. ego-based motives. For Barr et al. (2015), skyscrapers are being built as part of regeneration strategies and positive changes in business environment. This links to what Watts et al. (2007, p.461) call a 'Bilbao effect', i.e. 'where the regeneration inspired by one building can propagate the success of an entire city'. However, from a cost-benefit analysis perspective, these positive developments do not justify a pursuit for extreme heights.

Until more recently, however, it was thought that Skyscraper Indicator was unable to predict the UK crises due to the belief that this index was based on US or World market data. However, some research argues that the Skyscrapers Indicator is applicable in the UK (Skelton et al., 2010). The current study is therefore set to investigate whether Skyscraper Indicator can be used to appreciate potential corrections in the UK economy.

\section{MAIN CONTRIBUTION}

The research examined Skyscraper Indicator and its application in the UK. The study employed UK GDP and GDP per capita as a macro variables and a series of dummies for construction starts, durations and completions of the record-breaking buildings in the UK.

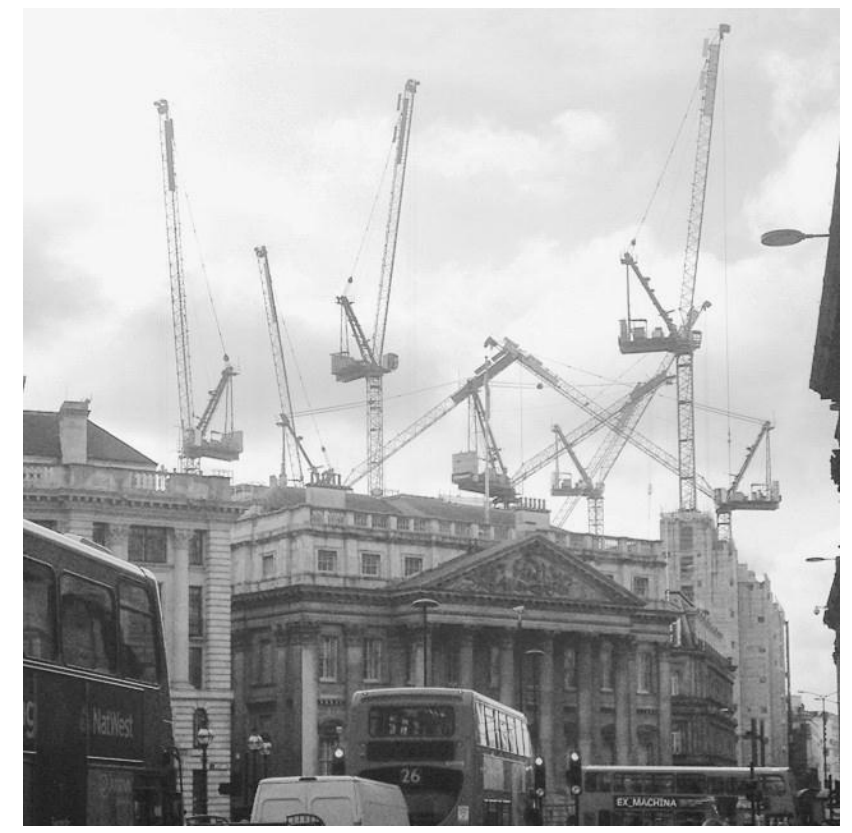

Figure 1. London skyline, February 2015

Source: courtesy of Karolis Adomaitis.

Surprisingly, the announcement to build the tallest building in the UK implies that the UK economy can be approaching its peak. Regression estimates confirm this hypothesis. 
Analysts are therefore advised to use the announcement of the construction of the record breaking skyscraper as a possible bell-weather in gaging future direction of the UK economy. They may turn their gaze towards the London skyline when contemplating UK market movements.

\section{PREVIOUS STUDIES}

The Skyscraper Indicator started with Lawrence's (1999) observation that construction of the world's tallest building conceded with an economic crisis. As Lawrence (2012, p.2) more recently observed, over the past one-an-a-half century this indicator has shown a negative correlation between construction of the next tallest building in the World and an impending financial crisis. For Lawrence (ibid.), availability of cheap money is the main cause for capital misallocation. Easily available capital triggers skyscraper construction with its completion during the economic contraction.

This Lawrence's idea has been extended with the most notable contributions by Thornton (2005), Barr (2010a; 2010b; 2013), Barr et al. (2015) and a series of articles published by the Economist (2006; 2010; 2015a; 2015b).

Thornton (2005) interpreted the Skyscraper Indicator in the light of 'Cantillon effect' and Austrian school's theory of the business cycle. Thornton appreciated limitations of the Skyscraper Indicator. First, indicator did not predict all major economic corrections such as depressions of 1920-21, 1937-38, and 1981-82. It then indicated recessions when downturns were insignificant such as that in 1913 and in the early 1970s. External factors such terrorism and the evolving nature of the economy could make it obsolete completely. However, acknowledging drawbacks of Skyscraper Indicator (like any other economic indicator), Thornton was positive about its ability to predict important downturns in the economy. The commentator presented with the chronology of major economic corrections and their association with the building of the world's tallest skyscrapers (Table 1).

Kaza (2010) added some more critique of the original idea presented by Lawrence (1999). According to the Kaza, Lawrence presented with a too narrow definition of the phenomenon. He missed an issue of entrepreneurial errors in building super-tall structures. He also based his observation on financial crises rather than economic contractions. Kaza subsequently provided additional evidence of skyscraper effects at the state levels. As his overview suggested, the tallest building in 40 US states where completed during economic contractions as identified by NBER (National Bureau of Economic Research), thus adding extra evidence for the usefulness of Skyscraper Indicator.

Barr (2010a) assessed the determinants of skyscraper building cycles in Manhattan over 110-year period from 1895 to 2004. The author developed a 'market for tall buildings' model which was based on two principle assumptions, i.e. rational and myopic expectations. The model incorporated average height and completions as depended variables. Regressors were New York City area population, national employment rate in FIRE (finance, insurance and real estate) industry, building costs, access to financing, property tax rates and zoning regulations, as well as set of dummy variables for specific government programmes. Empirically, myopic model fitted data better rejecting rational expectations model. Barr therefore hypothesised that a combination of long construction lags as well as semi-irreversibility of super tall building projects together with the irrational exuberance' have helped to determine the skyline of Manhattan. 
Barr (2010b) examined the determinants of skyscraper height for New York. The research covered 1859-2004 period. As the regression equation suggested, economic factors, including population growth and employment levels on one side and interest rates and building costs on the other, combined with land use regulation were significant in explaining building height in the city. Interestingly, the so called 'the quest for social status', i.e. builders engaging in height competition especially when economy was growing, would result in developers adding four to six more floors per project simply to overtake their peers.

In Barr (2013), the author compared the determinants of the market for skyscrapers in Chicago and New York over the 1885-2007 period. The dependent variables were the number of skyscraper completions and the height of the tallest building completed each year in the cities. Explanatory variables were the same as in Barr (2010a) with additional dummies for zoning in both cities. As regression estimates suggested, each city responded to the same variables differently. Thought the presence of strategic interaction across the two cities existed.

In a more recent study Barr et al. (2015) examined interrelationship between skyscraper height and business cycles in the United States, Canada, China and Hong Kong. The author employed Granger causality and cointegration tests to assess their claim. Announcement and completion dates for record-breaking skyscrapers were dependent variables. GDP per capita (as an output measure) was an explanatory variable. The estimates suggested that GDP per person and skyscraper height track each other with an output causing building heights. This led author to suggest that a growing economy and rising incomes fuelled developers' ego-based motives to stimulate building heights. Although, overall the research findings undermine claims that Skyscraper Indicators is a useful recession forecasting tool. On the contrary, the commentators cautioned when interpreting the underlying assumptions related to Skyscraper Indicators.

Garza (2012) applied Skyscraper Indicator onto 23 cities in Latin America. The author used building height as the dependent variable. The panel of explanatory variables included GDP of a given city, its area, height increase, dummy for a record breaking building, annual growth rate, dummy for residential building, $A R(1)$ term and time-control variable covering 1985-2010 period. His estimates were in a favour of traditional theory in explaining building height.

In 2006, the Economist ran a special report on the subject. The magazine started with two difficulties designers and developers are facing when considering skyscrapers. Difficulty one is economics. This is simply a demand for high-rise building as these structures do not appeal to all tenants and residents. Difficulty two is structure. Skyscrapers have low gross leasable area. What is more, they cost more and take longer to build; they are constrained by existing technology. This is why during economic expansion very few skyscrapers are being completed with most of them being speculatively developed. Nevertheless, the article continued suggesting that skyscrapers are alluring and developers continue building them.

In the following two articles, the Economist commented on the link between construction of record-setting buildings and financial crises. In the first article the Economist (2010a) has shown how a completion of Burj Khalifa, a tallest building in the World, coincided with the Global Financial Crisis. In the second piece, the Economist (2010b) 
commented on Clock Royal Tower Hotel in Mecca, Saudi Arabia as a possible bellwether for a likely economic correction in the country. More recently, the Economist (2015a) synthesised Barr's et al. (2015) findings. The magazine suggested a possible relationship between the construction of the tallest building in the world and economic crisis.

The literature illustrates the recent wide coverage Skyscraper Indicator received over the last decade. Researchers examined this phenomenon from a variety of historical and geographical perspectives but, surprisingly, without application to the UK economy. This study rectifies the oversight and investigates whether Skyscraper Indicator can be used to appreciate potential corrections in the UK economy.

Table 1. The World's tallest buildings and economic crises

\begin{tabular}{|c|c|c|c|c|}
\hline Completed & Building & Location & Height $(\mathbf{m})$ & Economic crisis \\
\hline 1908 & Singer & New York & 185 & Panic of 1907 \\
\hline 1909 & Metropolitan & New York & 212 & Panic of 1907 \\
\hline 1913 & Woolworth & New York & 240 & - \\
\hline 1929 & 40 Wall Street & New York & 281 & Great Depression \\
\hline 1930 & Chrysler & New York & 317 & Great Depression \\
\hline 1931 & Empire & New York & 379 & Great Depression \\
\hline $1972 / 73$ & World & New York & 420 & 1970 s stagflation \\
\hline 1974 & Sears & Chicago & 440 & 1970 s stagflation \\
\hline 1997 & Petronas Towers & Kuala Lumpur & 450 & Asian Crisis \\
\hline 2008 & Burj Khalifa & Dubai & 818 & Global Financial Crisis \\
\hline
\end{tabular}

Source: (Lawrence, 1999; Thornton, 2005; Bloch, 2010).

\section{DATA AND METHODOLOGY}

\section{Data}

The study uses UK GDP and GDP per capital quarterly series as macro variables. The series come from the Office for National Statistics (ONS, 2015) and cover Q1 1960-Q4 2014 period. Table 2 present series summary statistics. The use of both GDP estimates is substantiated from Barr et al. (2015). The commentators successfully employed both macroaggregates for the US, Canada, China and Hong Kong in assessing co-movements among skyscraper height and economic output.

Table 2. Summary statistics for UK GDP and GDP per capita series

\begin{tabular}{|c|c|c|c|c|c|c|c|}
\hline Series & Mean & St.dev. & $\begin{array}{c}\text { Kurto- } \\
\text { sis }\end{array}$ & Skewness & Min. & Max. & N \\
\hline GDP & 256652 & 95395 & -1.218 & 0.337 & 118220 & 429673 & 220 \\
\hline GDP p.c. & 2595 & 2251 & -1.184 & 0.487 & 123 & 7012 & 220 \\
\hline
\end{tabular}

Source: (ONS, 2015).

Considering that record-breaking height is a significant indicator of business cycle peak/trough, a series of dummy variables are computed for start, completion (opening day) and construction duration of the skyscraper. Table 2 lists all record-breaking buildings completed in the UK since 1970s. Looking at the start dates of the buildings, an interesting observation emerges - construction of these buildings coincided with economic expansion and their completion - with UK economic corrections. Construction of Guy's Tower started 
in April 1968 with UK's GDP growing 5.5 per cent that year. It was completed in May 1973 with UK GDP growth declining from 3.67 in Q4 1973 to -3.98 in Q1 1974, following three more quarters of negative growth (a recession). The similar chronology emerges for Tower 42 which construction started in second part of 1971, when UK GDP enjoyed 3.48 per cent growth. After 10 years in construction, it was opened in Q4 1980, when UK annual GDP went down -2.17 per cent. Other four buildings were also initiated at the height of economic expansion following their completions at the peak/turn of the economy, with most notable being the Shard, which construction began during the Global Financial Crisis.

Table 3. Tallest buildings in the UK and economic crises

\begin{tabular}{|c|c|c|c|c|c|}
\hline Building & Location & Start & Completion & Height $(\mathbf{m})$ & Economic crisis \\
\hline Guy's Tower* & London & Q2.1968 & Q2.1973 & 143 & 1970 's crisis \\
\hline Tower 42 & London & Q3.1971 & Q4.1980 & 182 & Thatcher crisis \\
\hline 1 Canada Square & London & Q1.1988 & Q1.1991 & 235 & 1980 's crisis \\
\hline Citi Tower & London & Q4.1998 & Q4.2001 & 200 & 1990 's financial crisis \\
\hline HSBC Tower & London & Q1.1999 & Q3.2002 & 210 & 1990 's financial crisis \\
\hline The Shard & London & Q1.2009 & Q3.2012 & 306 & Global Financial Crisis \\
\hline
\end{tabular}

* after a 140 million programme of repairs and environmental improvements, Guy's Tower now stands at $149 m$ (NHS, 2014)

Source: (NHS, 1976; Canary Wharf, 2015; CoStar, 2015).

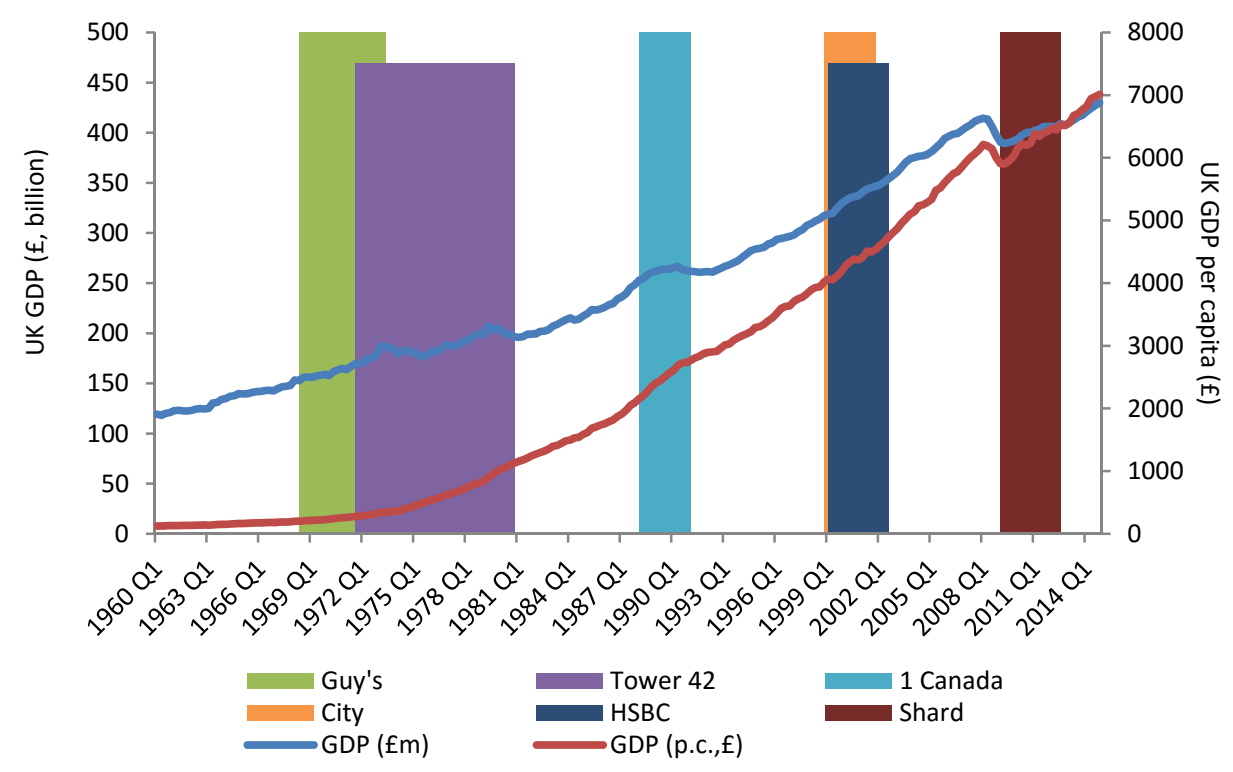

Figure 2. UK GDP series and dates of record breaking buildings Source: (Canary Wharf, 2015; CoStar, 2015; NHS, 1976; 2014). 


\section{Granger Causality with Dummy Variables}

The study then computes Granger causality with dummy variables to quantify causal effects between skyscrapers related variables and UK GDP (Koop, 2006; Barr et al., 2015):

$$
Y_{t}=\alpha+\theta Y_{t-q}+\beta D_{t-q}+e_{t}
$$

where:

$Y_{t}$ - is UK GDP series;

$D_{i t}$ - is skyscraper related dummy;

$e_{t}$ - is an error term;

$D_{1}$ - is dummy for start date;

$D_{2}$ - is dummy for completion (opening) date;

$D_{3}$ - is dummy for project duration.

Equations were modified with Newey-West (1987) estimator to remove instances of autocorrelation and heteroskedasticity in the error terms. Additionally, Breusch-Godfrey test for serial correlation in the residuals was performed. Where needed, equations were further modified by introducing an $A R(p)$ term to control for serial correlation.

\section{EMPIRICAL ESTIMATES}

The estimates for one-directional interdependence between GDP and the tallest building dummies are presented in Table 4 below. As it illustrates, there are statistically significant causal links between UK GDP and construction of the tallest building in the UK.

Construction starts came up as the most significant of all three dummy variables. Considering an aggregate GDP series, construction starts variable passed statistical threshold for all six buildings under the study (HSBC Tower construction starts dummy is significant at 10 per cent level). Unfortunately, neither building completions nor duration had the same degree of causal magnitude.

What's regarding GPD per capita series, again, construction starts dummy variable stood out as being significant in explaining national output. Although, it's weighting was less significant compared with the aggregate GDP series. Significance of the other two dummies varied within the sample.

The current estimates are somewhat rivalling Barr's et al. (2015) conclusion, who presented probably the most formal analysis of the Skyscraper Indicator, but are in line with the other publications on the subject. As noted above, Barr et al estimated that height and GDP per capita are cointegrated and that economic growth influences height. Their hypothesis however rejected the usefulness of Skyscraper Indicator as a leading indicator.

The opposite however applies for the UK. The decision to build the tallest building in the UK can provide some indication that the UK business cycle is reaching the peak. These estimates concur with Lawrence (1999; 2012), Thornton (2005), Garza (2012) and the Economist (2006; 2010a; 2010b; 2015a) who's commentaries were in favour of the Skyscraper Indicator theory.

Certainly, the current study was afflicted with a number of limitations. The sample size (the number of record breaking buildings and time-series duration) was limited. 
Table 4. Regression estimates

\begin{tabular}{|c|c|c|c|c|c|c|c|c|c|}
\hline \multirow[t]{2}{*}{ Dummy variables effect on GDP series } & \multicolumn{3}{|c|}{ Guy's Tower } & \multicolumn{3}{|c|}{ Tower 42} & \multicolumn{3}{|c|}{1 Canada Square } \\
\hline & Start & Completion & Duration & Start & Completion & Duration & Start & Completion & Duration \\
\hline \multirow[t]{2}{*}{ Coefficient } & -2928 & -1824 & 307.43 & 2177 & -1529 & -737 & 1641 & -200 & -392 \\
\hline & $(0.000)$ & $(0.227)$ & $(0.739)$ & $(0.000)$ & $(0.000)$ & $(0.265)$ & $(0.000)$ & $(0.597)$ & $(-0.525)$ \\
\hline R-sq. & 0.171 & 0.165 & 0.162 & 0.167 & 0.164 & 0.167 & 0.165 & 0.162 & 0.163 \\
\hline \multirow[t]{4}{*}{ B-G test } & 0.003 & 0.000 & 0.088 & 0.007 & 0.067 & 0.057 & 0.064 & 0.062 & 0.068 \\
\hline & $(0.955)$ & $(1.000)$ & $(0.764)$ & $(0.933)$ & $(0.796)$ & $(0.809)$ & $(0.799)$ & $(0.804)$ & $(0.792)$ \\
\hline & \multicolumn{3}{|c|}{ Citi Tower } & \multicolumn{3}{|c|}{ HSBC Tower } & \multicolumn{3}{|c|}{ The Shard } \\
\hline & Start & Completion & Duration & Start & Completion & Duration & Start & Completion & Duration \\
\hline \multirow[t]{2}{*}{ Coefficient } & 1551 & -967 & 772 & -1029 & 618 & 578 & -4588 & 2979 & 176 \\
\hline & $(0.000)$ & $(-4.269)$ & $(0.106)$ & $(0.070)$ & $(0.130)$ & $(0.151)$ & $(0.000)$ & $(0.000)$ & $(0.805)$ \\
\hline R-sq. & 0.164 & 0.163 & 0.164 & 0.163 & 0.162 & 0.163 & 0.183 & 0.171 & 0.162 \\
\hline \multirow[t]{2}{*}{ B-G test } & 0.020 & 0.078 & 0.016 & 0.069 & 0.051 & 0.023 & 0.386 & 0.025 & 0.068 \\
\hline & $(0.886)$ & $(0.778)$ & $(0.897)$ & $(0.791)$ & $(0.819)$ & $(0.877)$ & $(0.530)$ & $(0.873)$ & $(0.792)$ \\
\hline \multirow[t]{2}{*}{ Dummy variables effecton GDP per capita series } & \multicolumn{3}{|c|}{ Guy's Tower } & \multicolumn{3}{|c|}{ Tower 42} & \multicolumn{3}{|c|}{1 Canada Square } \\
\hline & Start & Completion & Duration & Start & Completion & Duration & Start & Completion & Duration \\
\hline \multirow[t]{2}{*}{ Coefficient } & -9.537 & -21.338 & -23.059 & -1.054 & 2.081 & -8.603 & 8.241 & 5.110 & 13.590 \\
\hline & $(0.051)$ & $(0.000)$ & $(0.000)$ & $(0.833)$ & $(0.386)$ & $(0.160)$ & $(0.212)$ & $(0.236)$ & $(0.110)$ \\
\hline R-sq. & 0.213 & 0.214 & 0.224 & 0.212 & 0.213 & 0.215 & 0.213 & 0.213 & 0.215 \\
\hline \multirow[t]{4}{*}{ B-G test } & 2.445 & 2.309 & 0.088 & 2.475 & 2.468 & 2.341 & 2.438 & 2.437 & 2.213 \\
\hline & $(0.116)$ & $(0.126)$ & $(0.764)$ & $(0.114)$ & $(0.114)$ & $(0.128)$ & $(0.116)$ & $(0.116)$ & $(0.134)$ \\
\hline & \multicolumn{3}{|c|}{ Citi Tower } & \multicolumn{3}{|c|}{ HSBC Tower } & \multicolumn{3}{|c|}{ The Shard } \\
\hline & Start & Completion & Duration & Start & Completion & Duration & Start & Completion & Duration \\
\hline \multirow[t]{2}{*}{ Coefficient } & 56.026 & -12.352 & 10.994 & 10.140 & 17.891 & 8.540 & -77.211 & 78.629 & 18.247 \\
\hline & $(0.000)$ & $(0.392)$ & $(0.465)$ & $(0.327)$ & $(0.004)$ & $(0.388)$ & $(0.000)$ & $(0.000)$ & $(0.359)$ \\
\hline R-sq. & 0.226 & 0.213 & 0.214 & 0.213 & 0.214 & 0.214 & 0.236 & 0.238 & 0.218 \\
\hline \multirow[t]{2}{*}{ B-G test } & 1.540 & 2.462 & 2.158 & 2.388 & 2.450 & 2.277 & 3.902 & 1.264 & 2.550 \\
\hline & $(0.211)$ & $(0.115)$ & $(0.139)$ & $(0.120)$ & $(0.115)$ & $(0.129)$ & $(0.048)$ & $(0.257)$ & $(0.108)$ \\
\hline
\end{tabular}

NB: Probability is in parentheses: * significant at $5 \%$ level; the number of lags in Breusch-Godfrey Serial Correlation LM Test (B-G test) is 1; all equations contain AR(2) term.

Both GDP and GDP per capita series were tested for stationarity; 1 st-diffrences series passed statistical muster at $5 \%$ confidence level:

GDP - ADF test: -6.724 , critical value -2.875 ; PP test: -10.691 , critical value -2.875 ;

Source: own study. 
What is more, construction period for each height-breaking building varied, i.e. it took almost 10 years for Tower 42 to be completed, while 1 Canada Square. Citi Tower and HSBC Tower were completed in 3 years' time. Moreover, no lead-lag relationship was tested for variables.

These limitations aside, the estimates suggest that one can potentially predict UK economic correction purely by looking at the city skyline. Certainly, skyscrapers have varying functions - some skyscrapers are symbols of prestige or iconic identity, others showcase the architectural achievements of modern capitalism (Thornton, 2005), while some simply provide shelter, security, privacy as well as facilitate intra-group and communication (Barr et al, 2015).

However, taken together, the current study provided some evidence that Skyscraper Indicator can be used as a leading indicator for the UK. Analysts are therefore advised to use the announcement of the construction of the record breaking skyscraper as an alternative indicator in gaging future direction of the UK economy.

Certainly, more research using alternative available techniques and data is needed to further support these findings. However, as the market develops, and more data becomes available, this creates opportunities for future inquiry.

\section{CONCLUSIONS}

It's been now four centuries since the widespread adoption of alloys and three centuries since the onset of the high-rise buildings. Since then, skyscrapers started dominating skyline of the cities. Last year, a record number of tall buildings were completed.

Curiously, the propagation of skyscrapers led economists to note an interesting interrelation between the construction of the tallest building and financial crises. Plausible explanations were postulated that during times of easy credit, with low interest rates, businesses expand and hire more people to produce their goods or services. Higher levels of activity trigger demand for space, which stimulates construction activity. A need for space, competition for land and 'cheap capital', makes a long-term capital intensive projects (skyscrapers) seem more attractive relative to short-term and less-capital intensive ones (shorter buildings). During the late phase of economic expansion, skyscraper projects proliferate but then the cycle turns. Ironically, as recession spreads, a glut of skyscrapers construction projects litters the skyline.

A number of publications have attempted to resolve the paradox, covering the gamut of academic journal articles to magazine or news stories but, curiously without properly examining the UK skyscraper situation. The estimates confirm the notion that the announcement of tallest building can forecast the UK business cycle peak. Analysts should therefore get concerned when looking at the London skyline. 


\section{REFERENCES}

Barr, J. (2010a). Skyscrapers and the Skyline: Manhattan, 1895-2004. Real Estate Economics, 38(3), 567-597.

Barr, J. (2010b). Skyscraper Height. The Journal of Real Estate Finance and Economics, 45(3), 723-753.

Barr, J. (2013). Skyscrapers and skylines: New York and Chicago, 1885-2007. Journal of Regional Science, 53(3), 369-391.

Barr, J., Mizrach, B., \& Mundra, K. (2011). Skyscraper Height and the Business Cycle: International Time Series Evidence. Rutgers University Newark Working Paper No.2011-003.

Barr, J., Mizrach, B., \& Mundra, K. (2015). Skyscraper height and the business cycle: separating myth from reality. Applied Economics, 47(2), 148-160.

Bloch, R. (2010). Dubai's Long Goodbye. International Journal of Urban and Regional Research, 34 (4), 943-951.

Briody, B. (2009). Four Engineering Breakthroughs Changing the Skyscraper Race. Retrieved from http://www.popularmechanics.com/technology/design/a5424/4244302

Canary Wharf (2015). Retrieved from http://group.canarywharf.com/the-estate/

Clark, W.C., \& Kingston, J.L. (1930). The Skyscraper: A Study in the Economic Height of Modern Office Buildings. Brattleboro, VT: American Institute of Steel Construction.

CoStar (2015). Analytics. Retrieved from http://gateway.costar.com/Gateway/

Flannery, R. (2015, August 3). Shanghai Tower: China's Tallest Building. Forbes. Retrieved from http://www.forbes.com/pictures/mil45mfdd/shanghai-tower-14/

Garza, N. (2012). Skyscrapers and the economy. Paper presented at $52^{\text {nd }}$ European Regional Science Association Congress, Bratislava.

Hanke, S. (2010, January). Booms and busts. GlobeAsia.

Helsley, R.W., \& Strange, W.C. (2008). A game-theoretic analysis of skyscrapers. Journal of Urban Economics, 64(1), 49-64.

Jadevicius, A., \& Huston, S. (2014). A "family of cycles"-major and auxiliary business cycles. Journal of Property Investment \& Finance, 32(3), 306-323.

Jivanda, T. (2014). Kingdom Tower: Construction of $1 \mathrm{~km}$ high new world's tallest building to begin next week in Saudi Arabia. Retrieved from http://www.independent.co.uk/arts-entertainment/architecture/kingdom-tower-construction-of-1 km-high-new-worlds-tallest-building-tobegin-next-week-9271191.html/

Kaza, G. (2010). Note: wolverines, razorbacks, and skyscrapers. The Quarterly Journal of Austrian Economics, 13(4), 74-79.

Knight Frank (2015). Global Cities: Skyscrapers. 2015 Report. Knight Frand/Newmark Grubb Report, New York.

Kononova, S. (2009). Russia Now: Gazprom's Okhta Centre skyscraper in St Petersburg causes disputes. Retrieved from http://www.dailymail.co.uk/news/article-1215848/St-Petersburg-authorities-allow-new-skyscraper-overshadow-world-heritage-site.html\#ixzz3XqZr5GeV

Koop, G. (2006). Analysis of Financial Data. London: John Wiley \& Sons.

Lawrence, A. (1999). The Curse Bites: Skyscraper Index Strikes. Property Report, Dresdner Kleinwort Benson Research, London.

Lawrence, A. (2012). Skyscraper Index: Bubble building. Barclays Capital Equity Research, London. 
Newey, W.K., \& West, K.D. (1987). A Simple, Positive Semi-definite, Heteroskedasticity and Autocorrelation Consistent Covariance Matrix. Econometrica, 55(3), 703-708.

NHS (1976). Guy's Tower. Guy's Hospital, London.

NHS (2014). Guy's Tower regains title as world's tallest hospital building. Retrieved from http://www.guysandstthomas.nhs.uk/news-and-events/2014-news/20140528-guystower.aspx/

ONS (2015). Key Economic Time Series Data. Retrieved from http://www.ons.gov.uk/ ons/site-information/using-the-website/time-series/index.html\#2

Roberts, W.L. (1983). Hot Rolling of Steel (Manufacturing Engineering and Materials Processing Series). New York: CRC Press.

Skelton, I.R., Bouchlaghem, D., Demian, P., \& Anumba, C. (2010). Tall building boom - now bust? In: Ghafoori, N. (2010) Challenges, Opportunities and Solutions in Structural Engineering and Construction. New York: CRC Press.

The Economist (2006). The Skyscraper Boom: Better than Flying. Retrieved from http://www.economist.com/node/7001496

The Economist (2010a). Tallest buildings: Look on my works, ye Mighty. [Retrieved from http://www.economist.com/node/15205024

The Economist (2010b). Hubris in brick and mortar. Retrieved from http://www. economist.com/blogs/freeexchange/2010/06/skyscrapers

The Economist (2015a). Towers of Babel. Is there such a thing as a skyscraper curse? Retrieved from http://www.economist.com/news/finance-and-economics/21647289-there-such-thing-skyscraper-curse-towers-babel

The Economist (2015b). Constructive one-upmanship. Retrieved from http://www. economist.com/blogs/graphicdetail/2015/04/daily-chart-13

Thornton, M. (2005). Skyscrapers and business cycles. The Quarterly Journal of Austrian Economics, 8(1), 51-74.

Watts, S., Kalita, N., \& Maclean, M. (2007). The economics of super-tall towers. The Structural Design of Tall and Special Buildings, 16(4), 457-470. 


\section{Author}

\section{Arvydas Jadevicius}

Arvydas Jadevicius has an extensive expertise in market research intelligence, data collection and investment analysis. He is a past-Chair of the European Real Estate Society PhD Network (20132014).

In 2014, Arvydas awarded a Doctorate for his work on UK commercial property forecasting accuracy and its improvement through combination forecasting. His research was awarded with the Construction Research and Innovation (CRI) prize (ARCOM, 2010) and the Best Paper Award on Real Estate Market Analysis at the American Real Estate Society Annual conference (ARES, 2014). Correspondence to: Arvydas Jadevicius can be contacted at a.jadevicius@gmail.com

\section{Acknowledgements and Financial Disclosure}

The author would like to thank Adam Phillips (CoStar), Elizabeth Adams (Canary Wharf), Natalie Henshall (Essentia) and Neil Allfrey (Penoyre \& Prasad) for providing dates on the tallest buildings in the UK and to Karolis Adomaitis for London skyline image. A special thanks goes to Simon Huston at the RAU for useful comments and suggestions regarding this manuscript.

\section{Copyright and License}

This article is published under the terms of the Creative Commons Attribution - NonCommercial - NoDerivs (CC BY-NC-ND 3.0) License http://creativecommons.org/licenses/by-nc-nd/3.0/ 